\title{
DILEMA ANTARA HOBI DAN BISNIS PERDAGANGAN BURUNG SERTA KONSERVASI BURUNG
}

\author{
Johan Iskandar \\ Departemen Biologi Fmipa, Pascasarjana PSMIL dan DIL serta Peneliti PPSDAL Unpad \\ *Alamat Korespondensi: jiskandar@unpad.ac.id
}

\begin{abstract}
Paper discusses result of study on the development of hobby on bird keeping, bird song contest, bird trade business, and conservation strategy for bird sustainable use, based on case study undertaken in the Bandung urban and surrounding areas. The combination of qualitative and quantitative method with descriptive analysis was used in this study. The result of study shows that based on direct inventory it was recorded 96 bird species of 24 families which were being kept by thirty respondents. Among the total species, 29 species and races were recorded as dominant, namely anis merah (Zoothera citrina), murai batu (Copsychus malabaricus), ciblek (Prinia familiaris), several races of kenari (Serinus canarinus), several races of lovebird (Agapornis spp), bentet/toed (Lanius schach), several races of pleci/burung kacamata (Zosterops palpebrosa), robin (Leothrix sp), and perkutut (Geopelia striata). Nowadays, the hobby of bird keeping in the cages has tended to increase caused of development of regular song bird contest in the local, regional and national level. Based on this study, it was recorded that fiveteen bird species have commonly entertained in the local song bird contests by the bird lovers in Bandung urban and surrounding areas. Development of the increasing bird keeping hobby and song bird contests have tended to develop bird trading in the urban bird markets and increasing bird hunting in the villages. Therefore, the activity of bird keeping hobby, song bird contests, and bird trading have been dilemma. On the one hand, these activities have provided some benefits. For example, it has developed the bird trading business and bird captive breeding undertaken by the bird lover communities and providing some economic benefits. On the other hands, these activities have affected to dramatically bird population decrease in nature due to increasing bird hunting in villages. Even some rare birds have high risk to be decrease and maybe disappear in some village areas in the near future. Therefore, to sustainable utilize bird species for fulfilling the hobby of bird keeping, bird contests and bird trading purpose; the conservation effort based on community participation is essentially needed.
\end{abstract}

Keywords: hobby of bird keeping, bird contest, bird trading business, bird conservation

\section{PENDAHULUAN}

Anekaragam burung memiliki fungsi penting bagi ekologi, sosial ekonomi dan budaya masyarakat. Fungsi ekologi burung misalnya berperan penting dalam membantu pengendalian hama pertanian, membantu penyerbukan tanaman atau tumbuhan, menyebarkan biji buah-buahan, sebagai indikator perubahan lingkungan, dan indikator perubahan musim (cf. Dammerman, 1929; Dickson et al., 1979; Howe dan Westley, 1988; Iskandar, 2015). Sementara itu, fungsi sosial ekonomi dan budaya burung bagi masyarakat, antara lain sebagai bahan piaraan dan bahan perdagangan yang menguntungkan (Iskandar, 1980; 1987). Kebiasaan memelihara burung sejatinya telah lama dikenal di masyarakat Indonesia. Bahkan secara tradisi di masa silam pada masyarakat Jawa, seorang pria Jawa dianggap berhasil dalam hidup apabila telah memiliki 5 hal utama, yaitu pekerjaan (narpadha); rumah (wismo); kuda, kereta atau kendaraan (turangga); istri (garwo); dan peliharaan burung (manuk atau kukila) (Brotoisworo dan Iskandar, 1984). Jadi, ditilik dari pandangan masyarakat Jawa, memelihara burung telah menjadi tradisi secara turun temurun. Jenis burung yang dianggap membawa keberuntungan bagi kehidupan Orang Jawa, yaitu burung perkutut (Geopelia striata) (Iskandar, 1980).
Dewasa ini, kebiasaan memelihara burung cenderung kian marak di berbagai etnik di Indonesia, terutama di masyarakat kota. Misalnya, menurut hasil kajian Jepson (2010) di 6 kota besar di Jawa Bali, seperti Jakarta, Bandung, Solo, Yogyakarta, Surabaya, dan Denpasar tercatat bahwa tiap satu dari 3 keluarga responden memelihara burung dan dua dari tiga keluarga responden tersebut pernah memelihara burung dalam masa sepuluh tahun terakhir. Maka, dengan maraknya hobi memelihara burung di masyarakat kota-kota besar, telah berkembang pula pasar-pasar burung. Hampir di setiap kota kabupaten/kotamadya dan provinsi di Indonesia ditemukan pasar burung. Misalnya saja, Pasar Burung Pramuka di Jakarta; Pasar Burung Sukahaji di Bandung; Pasar Burung Depok di Solo; Pasty (Pasar Burung dan Tanaman Hias Yogyakarta) di Yogyakarta; Pasar Burung Diponogoro di Surabaya, Pasar Burung Splendid di Malang; dan Pasar Burung Satria di Bali.

Seiring dengan kian maraknya hobi memelihara burung di kota-kota, telah berkembang pula kebiasaan kontes-kontes burung kicau di berbagai wilayah di Indonesia. Pengaruh kontes burung kicau tersebut dapat menyebabkan melambungnya harga burung yang biasa dikonteskan, terlebih bagi burung yang telah pernah menjadi juara dalam kontes. 
Pengaruh lebih jauh, jenis-jenis burung kontes tersebut laku dipedagangkan dan banyak diburu di berbagai pelosok pedesaan. Konsekuensinya, anekaragam burung di alam, contohnya burung cucak rawa populasinya merosot drastis sejak era 1980-an, akibat marak diburu dan diperdagangkan, serta dikonteskan (cf. Nash, 1994; Whitten dkk, 1999).

Karena itu, kegiatan hobi memelihara burung, kontes burung, dan bisnis perdagangan burung telah menyebabkan suatu dilema. Pada satu fihak, kegiatan tersebut dapat memberikan dampak positif. Misalnya, dapat berkembangnya kegiatan bisnis burung dan penangkaran burung oleh masyarakat yang dapat menguntungkan secara ekonomi. Namun, di fihak lain, kegiatan tersebut sangat mengkhawatirkan terjadinya penurunan populasi burung secara drastis di alam, bahkan dapat menimbulkan kepunahan jenis burung. Hal tersebut terutama apabila kegiatan seperti kontes burung dan bisnis perdagangan burung tersebut tidak dikelola dengan seksama, tanpa memperhatikan kaidah-kaidah konservasinya.

Tulisan ini mendiskusikan tentang perkembangan kegiatan hobi memelihara burung, kontes burung, bisnis perdagangan burung, dan strategi konservasi untuk pemanfaatan burung secara berkelanjutan, berdasarkan hasil studi kasus di Kota Bandung dan sekitarnya.

\section{BAHAN DAN METODE}

Bahan yang digunakan dalam penelitian ini adalah buku catatan lapangan, pensil, ballpoint, kamera, lemabaran kuesioner, dan buku identifikasi burung. Sementara itu, metoda penelitian yang digunakan dalam studi ini menerapkan pendekatan kualitatif bersifat deskriptif analisis. Selain itu, dikombinasikan pula dengan pendekatan kuantitatif secara terbatas. Teknik pengumpulan data, yaitu mencatat jenis-jenis burung dari 30 responden pemelihara burung, disertai dengan wawancara terhadap responden, baik wawancara secara deep interview dan wawancara berstuktur menggunakan kuesioner (cf. Newing et al, 2011). Pencatatan jenisjenis burung untuk aspek ekologi, dilakukan pencatatan tentang jenis-jenis burung, dan jumlah individu dari masing-masing jenis burung. Untuk indentifikasi jenis-jenis burung digunakan beberapa buku identifikasi jenis burung, seperti buku King dkk (1975), MacKinnon dkk (1998), dan Beehler et al (1986).

\section{HASIL DAN PEMBAHASAN \\ Hobi memelihara burung}

Ditilik dari sejarah ekologi, hobi memelihara burung oleh masyarakat Indonesia telah dikenal sejak lama. Paling tidak dari kasus di Kota Bandung, kebiasaan memelihara burung oleh masyarakat telah dikenal di era kolonial Belanda. Pada masa itu, misalnya dapat disaksikan anekaragam burung biasa dipiara di sangkar-sangkar yang digantungkan di langit-langit rumah orang Belanda maupun orang pribumi (Kunto, 1986).

Kini dalam perkembangannya, hobi memelihara burung di masyarakat kota Bandung cenderung kian marak. Misalnya saja, dari pengalaman empiris dapat disaksikan banyak warga Kota Bandung yang memelihara anekaragam burung, dengan ditempatkan di sangkar-sangkar dan digantung di langit-langit beranda rumah-rumah. Demimikan pula, di kios-kios di pinggiran jalan raya di berbagai wilayah Kota Bandung, banyak diperdagangkan anekaragam jenis burung untuk mensuplai kebutuhan macam-macam burung bagi penggemar pemelihara burung. Tidak hanya itu, di pasar burung Sukahaji, Jalan Peta, Bandung, ratusan jenis burung marak diperdagangkan untuk mensuplai kebutuhan para pemelihara burung di Kota Bandung (lihat Iskandar, 1980; Iskandar, 2013).

Berdasarkan hasil wawancara terhadap 30 responden pemelihara burung di kawasan Bandung dan sekitarnya diketahui ada beberapa alasan responden hobi memelihara burung. Yakni sebagai sarana hiburan karena burung memiliki bulu indah, suara merdu, serta tingkah laku lucu menarik $(60,00$ $\%)$; untuk hobi dan menguntungkan untuk dijual lagi (16.67\%); untuk hobi dan menghilangkan stress dan rasa penat $(13,33 \%)$; untuk hobi dan cukup tersedia waktu untuk memelihara burung $(6,67 \%)$; serta untuk hobi dan dapat memperbanyak pertemanan di antara komunitas pemelihara burung $(3,33 \%)$.

Berdasarkan studi ini, dapat disimak bahwa kini para responden dari para pemelihara burung di kota, tujuan memelihara burung sudah berbeda dengan tradisi di masa silam. Kini, tujuan memelihara burung, bukan lagi sekedar untuk kepuasan batin, tapi juga dilandasi untuk kepentingan bisnis. Konsekuensinya, aneka ragam burung laku diperdagangkan dan sangat menguntungkan.

\section{Keanenekaan jenis burung}

Berdasarkan pencatatan jenis-jenis burung piaraan dari 30 responden. Hasilnya dapat dicatat total 96 jenis dari 24 famili burung yang marak dipelihara oleh ketigapuluh responden. Jumlah individu dari masing-masing jenis burung sangat bervariasi. Misalnya, untuk jenis-jenis ungkut-ungkut (Megalaema haemacephala), bultok (Megalema corvina), nuri (Eclectus roratus), dan srigunting (Dicrurus macrocercus) tercatat memiliki jumlah individu rendah hanya berkisar 1-5 ekor yang biasa dipiara responden. Dari berbagai jenis burung tersebut, tercatat pula diantaranya jenis-jenis burung yang kategori dilindungi undang-undang di Indonesia dan masuk daftar CITES appendix 1 dan appendix 2 (cf. Noerdjito \& Muryanto, 2001; Soehartono dan Mardiastuti, 2003), tapi dipelihara responden. Contohnya, jalak putih Bali (Leucopsar rotchildi), jalak putih (Sturnus melanopterus), kelaces (Arachnothera longirostra), dan elang rawa (Circus aproximans). Secara hukum, sebenarnya jenis-jenis 
burung tersebut dilarang untuk dipiara ataupun diperdagangkan. Sementara itu, 29 jenis burung lainnya (30\% terhadap total), tercatat memiliki individu tinggi dipiara responden, dengan jumlah individu tiap jenisnya berkisar 10-200-an ekor, seperti anis merah (Zoothera citrina), ciblek (Prinia familiaris), cucak hijau (Chloropsis sonneratii), kacer/murai (Copsychus saularis), kenari (Serinus canarinus) dengan 24 variasi/ras, love bird (Agapornis spp) dengan 3 ras, murai batu (Copsychus malabaricus), parkit (Melopsittacus undulatus) dengan 4 ras, pentet/toed (Lanius schach), perkutut (Geopelia striata), pleci/burung kacama mata (Zosterops palpebrosa) dengan 4 ras/jenis, robin (Leothrix sp), puyuh petelur (Coturnix coturnix), dan merpati (Columba livia). Maka, ditilik dari keanekaan jenis burung yang dipiara para responen, secara umum sangat beranekaragam. Terutama jenisjenis burung relatif mudah dipiara atau diternakan, seperti kenari, lovebird, parkit, puyuh petelur, dan merpati. Selain itu juga, beberapa jenis burung yang biasa marak dikonteskan umum dipiara oleh para responden, seperti anis merah, murai batu, pentet/toed dan pleci/burung kacamata.

\section{Kontes burung kicau}

Berdasarkan pendapat para informan, diketahui bahwa kontes burung kicau pasca reformasi dan krismon (pasca tahun 1998), tidak lagi diselenggarakan secara sentralistik di Jakarta dan penyelenggarannya pun tidak dimonopoli oleh PBI (Perhimpunan Burung Indonesia). Namun, dewasa ini kontes burung kicau marak diselenggarakan di berbagai daerah di Jawa Barat, Jawa Tengah, dan Jawa Timur, dengan diselenggarakan oleh berbagai kelompok organisasi 'bird club', pelaksana (EO=Event Organizer) lokal secara mandiri ataupun bekerjasama dengan BnR atau Ebod Jaya. Di Kota Bandung dan sekitarnya, tercatat puluhan kelompok pelaksana kontes burung kicau di tingkat lokal. Oleh karena itu, hampir tiap hari marak dilaksanakan kontes burung oleh berbagai 'bird club' tersebut. Sementara itu, secara nasional, pelaksaan kontes burung kicau di Indonesia dapat dibedakan atas 3 tingkatan, yaitu kontes di tingkat lokal, kontes di tingkat regional dan kontes di tingkat nasional.

Kontes burung kicau di tingkat lokal atau biasa disebut pula oleh para kicau mania sebagai latihan bersama (latber) di Kota Bandung dan sekitarnya biasanya diselenggarakan secara rutin setiap minggu oleh tiap kelompok pelaksana kontes lokal. Disamping itu juga kontes burung kicau biasa dilaksanakan secara non-rutin, dikaitkan dengan perayaan penting tertentu, seperti Hari Ulang Tahun (HUT) TVRI Jabar, HUT Kapolda, HUT Pangdam Siliwangi, HUT Koran Pikiran Rakyat, dan lain-lain. Informasi kontes burung secara lengkap biasa dimuat secara rutin tiap terbitan hari Rabu di Koran lokal Gala Media. Peserta kontes burung kicau di tingkat lokal biasanya diikuti oleh para pemelihara burung di
Kota Bandung dan sekitarnya. Sedangkan kontes burung kicau di tingkat regional biasa dilaksanakan secara rutin tiap 3 bulan, dengan diikuti oleh para juara kontes burung di tingkat lokal di Jawa Barat. Sementara itu, kontes burung di tingkat nasional biasa dilaksanakan secara rutin antara tiap 6 bulan atau tiap tahun. Para peserta kontes burung tingkat nasional biasanya diikuti oleh para pemenang di tingkat regional di seluruh Indonesia.

Jenis-jenis burung yang biasa disertakan pada kontes burung kicau tingkat lokal di Kota Bandung dan sekitarnya cukup beraneka ragam. Utamanya ada dua jenis burung lokal yang biasa dijadikan unggulan kontes, yaitu murai batu (Copsychus malabaricus) dan anis merah (Zoothera citrina). Disamping itu, 13 jenis burung lainnya biasa pula disertakan dalam kontes.Yaitu sejatinya jenis-jenis burung tersebut merupakan burung piaraan yang khusus dijadikan burung pengisi suara (master) dari dua jenis burung utama dalam kontes, burung murai batu dan burung anis merah. Namun, dalam perkembangannya, anekaragam jenis burung master tersebut juga sangat marak dikonteskan. Dengan demikian, secara keseluruhan, tercatat minimal 20 jenis burung yang biasa dikonteskan para kicau mania di tingkat lokal, Kota Bandung; tingkat regional; dan tingkat nasional. Dari sejumlah jenis tersebut, 15 jenis burung di antaranya sangat umum dikonteskan di tingkat lokal, yakni murai batu, anis merah, lovebird (Agapornis sp), kacer (Copsychus saularis), cucak jenggot (Criniger bres), cucak hijau (Chloropsis sonneratii), pentet/toed (Lanius schach), gelatik batu (Parus major), ciblek (Prinia familiaris), kutilang (Picnonotus aurigaster), kenari (Serius canarius), parkit (Melopsittacus undulatus), jalak suren (Sturnus contra), anis kembang (Zoothera interpres), dan pleci/burung kacamata (Zosterops palpebrosa). Sementara itu, 5 jenis lainnya, yaitu burung rio-rio (Scissirostrum dubium), cucak rawa (Pycnonotus zeylanica), tledekan (Cyornis banyumas), Cililin (Platylopus glareliculatus), dan branjangan (Mirafra javanica), biasa pula dikonteskan di tingkat regional dan nasional.

Pada kontes burung tingkat lokal, kualitas burung yang dikonteskan sangat bervariasi. Mengingat acara kontes tersebut juga biasa dijadikan ajang latihan bagi burung-burung pemula ikut kontes burung kicau. Para peserta kontes biasanya dibedakan 3 kelas. Pada tiap kelas diikuti oleh 20-30 peserta. Bayar tiket untuk ikut serta dalam kontes burung kicau di tingkat lokal relatif masih murah. Pada kelas pertama, bayarnya rata-rata sekitar $\mathrm{Rp}$ 40.000-Rp 50.000. Sementara itu, untuk kelas dua dan tiganya dengan bayar tiket sekitar Rp 20.000-Rp 30.000.

Beberapa aspek yang dinilai dalam kontes burung, antara lain lagu/irama (variasi jenis lagu), volume/suara (keras dan bersihnya suara), durasi/stamina (kicau terus/gacor) dan fisik/gaya (terus tengger/gaya teler). 
Burung yang menjadi juara kontes, dibagi menjadi juara 1 hingga juara 4 juara atau bahkan hingga juara 9 atau 10, dengan masing-masing juara diberi hadiah dan piagam. Besaran hadiah biasanya disesuaikan dengan penghasilan dari penjualan tiket ataupun adakalanya ditambah dari sponsor, seperti Bnr, Ebod Jaya dan lain-lain. Hadiah bagi para juara bervariasi sekitar Rp 35.000-Rp 1.000.000. Untuk kontes burung kicau di tingkat regional, biasanya dilakukan tiap 3 bulan. Lokasi penyelenggaraannya biasanya di tempat-tempat yang telah ditentukan oleh $\mathrm{BnR}$ atau PBI. Untuk mendapatkan tiket harus pesan dan tidak bisa memilih nomor gantungan. Bayar tiket tersebut umumnya lebih mahal dari bayar tiket untuk kontes tingkat lokal/latihan, yaitu berkisar Rp 50.000-Rp 250.000.

Para peserta kontes burung di tingkat regional tersebut biasanya diiukuti oleh para pemenang kontes burung di tingkat lokal di berbagai daerah di Jabar, seperti Bogor, Tangerang dan Bekasi. Jumlah peserta lomba pada tingkat regional mencapai sekitar 70 peserta/gantangan. Mengingat lebih dari sejumlah tersebut cukup sulit dalam penilaiannya.

Besaran hadiah bagi pemenang lomba regional lebih tinggi dibandingkan di tingkat lokal, yaitu berkisar $\mathrm{Rp}$ 70.000-Rp 5.000.000. Besaran hadiah tersebut biasanya ditentukan oleh pemasukan dari tiket dan juga masukan dari sponsor, seperti produksi rokok, produksi pakan burung, obat-obatan burung dan produksi sangkar. Sementara itu, kontes burung pada tingkat nasional biasanya dilakukan pada tiap 6 bulan sekali ataupun setahun sekali. Para peserta lomba biasanya dari berbagai provinsi di Indonesia. Harga tiket untuk peserta lomba di tingkat nasional Rp 200.000-2,5 juta. Sementara itu, hadiah bagi para pemenang lomba biasanya nilainya puluhan juta. Pada lomba tingkat regional dan nasional pesertanya diutamakan burung-burung hasil penangkaran (pakai ring). Namun demikian, burung kelompok non-ring juga masih marak diikusertakan dalam burung kontes burung kicau tersebut.

\section{Berbagai dampak}

Maraknya hobi memelihara burung dan kontes burung di kota telah menyebabkan berbagai dampak positif dan negatif. Dampak positifnya, antara lain berkembangnya bisnis burung yang sangat menguntungkan dan berkembangnya kegiatan penangkaran burung oleh masyarakat. Misalnya, dengan maraknya hobi memelihara burung dan kontes burung di kota, telah berkembang perdagangan burung di pasar-pasar burung di kota. Selain itu, seiring dengan maraknya hobi memelihara burung dan kontes burung, telah berkembang pula perdagangan sangkar-sangkar burung, anekaragam pakan burung, dan obat-obatan dan vitamin burung. Kesemua kegiatan itu dapat memberikan berbagai keuntungan pada banyak pihak, seperti penduduk desa para pemburu burung, para bandar burung di tingkat desa hingga kota, para pedagang pakan burung dan obat-obatan dan vitamin burung, serta para industri pembuat sangkar-sangkar burung (Iskandar, 2013). Tidak itu saja, dengan maraknya hobi memelihara burung dan kontes burung, telah berkembang pula berbagai kegiatan penangkaran burung di masyarakat. Misalnya, kini beberapa jenis burung, baik burung impor maupun burung lokal, seperti kenari, parkit, lovebird, murai batu, murai, anis merah, ciblek, cucak hijau, cucak jenggot, dan cucak rowo telah berhasil ditangkar oleh para kicau mania di Indonesia (lihat Sopandi, 1968; Widodo, 1996; Fauzi, 2012; Turut, 2012; Gacor, 2014; Murai, 2014; Putrawanto (nd), Prawoto (n.d), Gunawan (nd)). Selain memberi keuntungan ekonomi, kegiatan tersebut juga telah memicu berkembangnya pengetahuan lokal (local knowlege) penduduk tentang berbagai aspek biologi burung (ornitologi). Misalnya saja, pengetahuan tentang aneka ragam ras burung lokal, pembiakan dan perawatan burung.

Di samping memberikan dampak positif, maraknya hobi memelihara burung dan menyelenggarakan kontes burung telah menyebabkan pula rentetan dampak negatif. Misalnya, akibat maraknya hobi tersebut, telah memicu maraknya perburuan aneka ragam burung di berbagai pelosok pedesaan. Pasalnya, anekaragam burung, khususnya jenis burung yang biasa dikonteskan menjadi laku dijual. Harga burung tersebut yang tadinya di desa relatif murah. Namun, jenis-jenis burung tersebut setelah dibawa ke kota harganya menjadi melonjak tinggi. Misalnya saja, burung anis merah di pedesaan DAS Cisokan, Cianjur, Jawa Barat, harga jualnya cukup murah sekitar Rp 400.000-Rp 500.000. Tapi, harga burung tersebut setelah dibawa ke pasar burung kota kecamatan di Cianjur, meningkat menjadi sekitar Rp 500.000-Rp 5.000.000. Burung murai/kacer harga desa Cisokan laku sekitar $\mathrm{Rp}$ 250.000-Rp300.000. Tapi, setelah dibawa ke pasar kecamatan Cianjur, harganya meningkat menjadi $\mathrm{Rp}$ 500.000-Rp 700.000. Burung toed/pentet di desa Cisokan harganya Rp 50.000-Rp 75.000, sedangkan di pasar burung kecamatan di Cianjur laku Rp 100.000-Rp 300.000. Sedangkan jenis burung lainnya, burung pleci harganya di desa Cisokan laku dijual Rp 15.000-Rp 20.000, dan di kota kecamatan di Cianjur harganya meningkat menjadi $\mathrm{Rp} R \mathrm{p}$ 50.000-Rp 100.000. Sementara itu, jenis burung ciblek yang harganya di desa cukup murah di desa Cisokan sekitar Rp 50.000-Rp 60.000, sedangkan di pasar burung kecamatan di Cianjur harganya meningkat menjadi Rp 100.000-Rp1.000.000 (Aprillia, 2015). Bahkan, jenis-jenis burung tersebut, apabila telah jinak atupun telah menjadi juara kotes, harganya dapat meningkat secara drastis. Misalnya saja, jenis burung anis merah (Zoothera citrina) yang telah jinak dapat diperdagangan via dunia maya, serta laku dijual dengan harga Rp 12 juta hingga Rp 50 juta (Majalah Trubus, September 2013/XLIV hal.14).

\section{Upaya konservasi}


Jenis-jenis burung termasuk kategori sumberdaya alam terbaharukan (renewable resource). Jumlah populasi burung tersebut di alam mengalami dinamika setiap waktu, tergantung dari faktor laju asupan dan laju keluaran dari stok populasi burung. Faktor asupan terhadap populasi burung yaitu berupa laju anakan/berbiak dari burung tersebut. Sementara itu, laju keluaran dari stok populasi burung berupa laju penurunan populasi burung, akibat kematian burung, pengaruh dari berbagai sebab, seperti karena telah tua dan/atau karena penyakit; rusak dan/atau kehilangan habitat; dan akibat perburuan liar untuk dipelihara, diperdagangkan dan dikonteskan di kotakota.

Maka, ditilik dari model dinamika populasi burung tersebut, menunjukkan bahwa laju ekploitasi populasi aneka ragam burung di alam di berbagai wilayah di Indonesia cenderung melebihi laju jumlah anakan/regenerasi dari anekaragam burung tersebut. Akibatnya, populasi anekaragam burung, terutama jenis-jenis burung yang biasa marak dipiara, diperdagangkan, dan dikonteskan di alam populasinya setiap saat cenderung menurun secara drastis, sehingga mengancam kepunahan anekaragam burung di alam.

Oleh karena itu, guna memanfaatkan burung secara berkelanjutan, antara lain untuk kepentingan piaraan, kegiatan kontes, serta bisnis burung. Maka, perlunya upaya konservasi burung berbasis partisipasi aktif masyarakat. Misalnya saja, untuk jenis-jenis burung yang biasa marak dikonteskan, seyogianya diutamakan dari hasil penangkaran. Serta, upaya untuk mendorong kegiatan penangkaran burung, antara lain seyogianya di dalam penilaian untuk juara kontes, tidak hanya berlandaskan pada lagu/irama lagu, volume/suara kicau, durasi/stamina waktu kicau, dan fisik/gaya burung; tapi, juga pada kepemilikan 'sertifikat' asa-usul tentang keterangan jenis burung dari hasil penangkaran.

Namun, sayangnya kini dalam pelaksanaan kontes burung kicau, terutama di daerah-daerah, masih marak mengkonteskan anekaragam burung lokal bukan hasil penangkaran, non-ring atau nonsertifikat. Konsekuensinya, kini perburuan burung liar di alam sangat marak. Pasalnya, burung laku diperjualkan di kota-kota, untuk dipiara dan dikonteskan oleh masyarakat kota.

\section{KESIMPULAN}

Beradasarkan hasil studi ini dapat disimpulkan sebagai berikut;

1. Kegiatan hobi memelihara burung kini cenderung meningkat di Kota Bandung dan sekitarnya, termasuk pula di berbagai kota lainnya di Indonesia.

2. Maraknya hobi memelihara burung di masyarakat kota Bandung dan sekitarnya, antara lain seiring dengan kian maraknya kontes-kontes burung di tingkat lokal, regional, dan nasional di Indonesia.
3. Maraknya pemeliharaan anekaragam burung dan kontes burung di kota Bandung dan sekitarnya, telah menyebabkan pula maraknya perdagangan anekaragam burung di pasar-pasar burung di kota, seperti pasar burung Sukahaji, Kota Bandung.

4. Semakin maraknya hobi pemeliharaan burung, perdagangan burung, dan kontes-kontes burung di kota, sungguh mengkhawatirkan terhadap kepunahan burung di alam. Karena itu, untuk dapat memanfaatkan burung secara berkelanjutan, perlunya upaya konservasi berbasis masyarakat. Misalnya saja, konteskontes burung kicau hanya diperkenankan terhadap burung hasil penangkaran dan ditandai dengan memiliki sertifikat dan diberi tanda cincin. Selain itu, penilaian juara kontes burung kicau, seyogianya tidak hanya berdasarkan pada lagu/irama kicau, volume/suara kicau, durasi/stamina burung kicau, dan fisik/gaya burung, tapi juga berdasarkan memiliki 'sertifikat' keterangan burung asal-usul burung dari hasil penangkaran.

\section{Saran}

1. Disarankan untuk lebih menggiatkan lagi upayaupaya penangkaran anekaragam burung, baik burung impor maupun burung lokal, sehingga kebutuhan burung untuk dipelihara, dipedagangkan, dan dikonteskan, tidak lagi mengandalkan dari hasil perburuan burungburung liar di alam. Selain itu, untuk pengembangkan penangkaran tersebut perlunya peningkatan kerjasama secara sinergi antara masyarakat para penangkar burung, perguruan tinggi, lembaga penelitian, kebun bintang, taman safari dan lainnya.

2. Kegiatan-kegiatan kontes burung kicau disarankan seyogianya lebih diutamakan pada kontes burung hasil penangkaran, dan dalam peniliain kontes burung tidak saja dinilai lagu/irama kicau, volume/suara kicau, durasi/stamina burung berkicau, dan fisik/gaya burung, tapi juga memiliki sertifikat keterangan asal-usul burung hasil penangkaran, sehingga dapat mendorong pengembangan penangkaran dan menekan perburuan liar di alam.

3. Disarankan pengembangan hobi di masyarakat, bukan hanya hobi untuk 'mencintai burung' dipelihara dalam sangkar-sangkar, tapi juga perlunya pengenbangan hobi untuk 'mencintai' burung yang hidup di alam. Misalnya, perlunya ditumbuhkembangkan hobi rekreasi di alam/ekowisata dan hobi mengamati burung di alam (birdwatching), yang dapat bermanfaat untuk rekreasi dan memonitor populasi anekaragam burung di alam. 


\section{DAFTAR PUSTAKA}

Aprillia, E. 2015. Gangguan Aktivitas Manusia Terhadap Struktur Komunitas Burung di Daerah Rencana Proyek Pembangunan PLTA Cisokan, Jawa Barat. Skripsi Pada Prodi Biologi FMIPA, Unpad (tidak diterbitkan).

Beehler, B.M., Pratt, T.K., Zimmerman, D.A. 1986. Birds of New Guinea. Princeton: Princeton University Press.

Brotoisworo , E. and J.Iskandar, 1984. Problems of bird protection in Indonesia: a case study on Java. 10th Asian Continental Conference Sri Langka.

Dammerman, K.W. 1929. The Agricultural Zoology of the Malay Archipelago: The Animals Injurious and Beneficial to Agriculture, Horticulture and Forestry in the Malay Peninsula, The Dutch East Indies and the Philippines. Amterdam: J.H. De Bussy Ltd.

Dickson, J.G., R.N. Conner, R.R. Fleet, J.C. Kroll, J.A. Jackson (eds), 1979. The Role of Insectivorous in Forest Ecosystems. New York: Academic Press.

Fauzi, F.N. 2012. Parkit: Memelihara dan Menangkar. Klaten: PT Hamafira

Gacor, O.S. 2014. Buku Pintar Budidaya \& Pemasteran Cucak Hijau dan Cucak Jenggot. Yogyakarta: Flashbooks.

Gunawan, H. (nd). Budidaya \& Pemasteran Burung Cucak Rawa Plus Cucak Jenggot Cucak Jenggot Siap Tarum Dalam Kontes. Yogyakarta: Penerbit Pustaka Baru Press.

Gunawan, H. (nd). Budidaya \& Pemasteran Burung Ciblek Siap Tanding Menjadi Jawara Kontes. Yogyakarta: Penerbit Pustaka Baru Press.

Howe, H.F and L.C. Westley, 1988. Ecological Relationships of Plants and Animals. Oxford: Oxford University Press.

Iskandar, J. 1980. Penelitian Ekologi Burung di Beberapa Pedesaan di Daerah Aliran Sungai Citarum. Bandung: Skripsi pada Jurusan Biologi, Universitas Padjadjaran.

Iskandar, J. 2007. Keanekaan Jenis Burung Dan Dinamikanya Dalam Kehidupan Masyarakat Sunda. Bandung: Seri Sundalana, Pusat Studi Sunda.

Iskandar, J. 2013. Dilema Perdagangan Untuk Membantu Kesejahteraan Penduduk dan Perlindungan Lingkungan: Studi Kasus Perdagangan Burung di Kota Bandung. Proseding Seminar Nasional di Jurusan Biologi, FMIPA Unpad.

Iskandar, J. 2015. Keanekaan Hayati Binatang dan Manfaat Ekologi Bagi Manusia. Yogyakarta: Graha Ilmu.

Jepson, P. 2010. Towards and Indonesian Bird Conservation Ethos: Rflections from a Study of Bird-keeping in the Cities of Java and Bali. Dalam Tidemann, S. and A.Gosler (eds), Ethnoornithology: Birds, Indigenous Peoples, Culture and Society. London-Washington: Earthscan. Pp.313-330.

King, B., E.C. Dickinson and M. Woodcock, 1975. A Field Guide to the Birds of South East Asia. London: Collins.

Kunto, H. 1986. Semerbak Bunga di Kota Bandung Raya. Bandung: PT Granesia.

MacKinnon, J., Phillips, Van Balen, B. 1992. Burung-Burung di Sumatera, Jawa, Bali dan Kalimantan. Bogor: LIPI/Birdlife-Indonesia Programme.

Murai, O.H., 2014. Rahasia Sukses Beternak dan Memaster Murai Batu. Yogyakarta: Flashbook.

Nash, S.V. 1994. Going for a song: the trade in SE Asian non-Cites birds. Traffic, Cambridge.

Newing, H., C.Eagle, R.Puri, C.W.Watson, 2011. Conducting Research in Conservation: A Social Science Prespective. London and New York: Routledge.

Noerdjito, M \& I.Muryanto (eds), 2001. Jenis-Jenis Hayati Yang Dilindungi Undang-Undang di Indonesia. Cibinong: LIPI \& Nature Conservancy.

Prawoto, B. (nd), Memelihara dan Menangkar Lovebird. Klaten: Sahabat.

Putrawanto, I. (tanpa tahun). Budidaya \& Pemasteran Burung Kacer Siap Menjadi Jawara Kontes. Yogyakarta: Penerbit Pustaka Baru Press.

Soehartono, T. dan A.Mardiastuti, 20003. Pelaksanaan Konvensi CITES di Indonesia. Jakarta: JICA.

Sopandi, E.K. 1968. Mengenal dan Beternak Burung Kenari. Jogjakarta-Djakarta: Dian Publishing Company.

Turut, R., 2012. Burung Ocehan Juara Kontes. Depok: Penebar Swadaya.

Whitten, T., R.E. Soeriatmadja, S.Afiif, 1999. Ekologi Jawa dan Bali. Jakarta: Prenhallindo.

Widodo, W. 1996. Parkit. Depok: PT Penebar Swadaya. 